\title{
Phytoprotection
}

\section{Impact of soil microorganisms on weed biology and ecology}

\section{S.M. Boyetchko}

Volume 77, numéro 1, 1996

URI : https://id.erudit.org/iderudit/706099ar

DOI : https://doi.org/10.7202/706099ar

Aller au sommaire du numéro

\section{Éditeur(s)}

Société de protection des plantes du Québec (SPPQ)l

\section{ISSN}

0031-9511 (imprimé)

1710-1603 (numérique)

\section{Découvrir la revue}

\section{Citer cet article}

Boyetchko, S. (1996). Impact of soil microorganisms on weed biology and ecology. Phytoprotection, 77(1), 41-56. https://doi.org/10.7202/706099ar

\section{Résumé de l'article}

Quoique les populations de mauvaises herbes aient été traditionnellement réprimées par des méthodes chimiques et culturales, la lutte biologique par inondation du milieu avec des agents microbiens représente une stratégie supplémentaire de gestion des mauvaises herbes. Les agents pathogènes foliaires ont longtemps fait l'objet de recherches comme agents de lutte biologique potentiels, mais les microorganismes de la rhizosphere et leur influence sur la croissance et le développement des mauvaises herbes ont été ignorés jusqu'à tout récemment. Le sol de la rhizosphere contient une multitude de microorganismes, tels les rhizobactéries, les champignons phytopathogènes présents dans le sol et les champignons mycorhiziens à arbuscules, qui ont tous un impact direct ou indirect sur les mauvaises herbes et sur leur aptitude à la compétition. Dans certains cas, des microorganismes spécifiques ont un effet nuisible sur les mauvaises herbes et ils peuvent être exploités comme agents de lutte biologique. Les champignons mycorhiziens, omniprésents, sont des symbiotes bénéfiques qui peuvent transmetttre un avantage compétitif à leurs plantes-hôtes, tout particulièrement si la dépendance mycorhizienne s'exprime chez les mauvaises herbes plutôt que chez les cultures. Il peut être possible de tirer profit des divers microorganismes du sol en réduisant directement ou directement la compétition des mauvaises herbes et en faisant pencher l'avantage compétitif en faveur de la culture. Cependant les connaissances actuelles sur les relations entre les micro-organismes, les mauvaises herbes et les cultures sont limitées. Des efforts de recherche sont requis afin d'explorer l'utilisation des microorganismes du sol comme autre outil de lutte contre les mauvaises herbes.
Ce document est protégé par la loi sur le droit d'auteur. L'utilisation des services d'Érudit (y compris la reproduction) est assujettie à sa politique d'utilisation que vous pouvez consulter en ligne.

https://apropos.erudit.org/fr/usagers/politique-dutilisation/ 
Symposium on Weed Ecology

Expert Committee on Weeds - Edmonton 1993

Symposium sur l'écologie des adventices

Comité d'experts en malherbologie - Edmonton 1993

\title{
Impact of soil microorganisms on weed biology and ecology
}

\author{
Susan M. Boyetchko'
}

Received 1995-07-14; accepted 1996-05-15

While weed populations have traditionally been controlled by chemical and cultural methods, inundative biological control with microbial agents offers an additional strategy for managing weeds. Foliar pathogens have long been sought after as potential biocontrol agents, but rhizosphere microorganisms and their influence on weed growth and development have been ignored until recently. Rhizosphere soil is replete with a variety of microorganisms such as rhizobacteria, pathogenic soil-borne fungi, and arbuscular mycorrhizal fungi, all of which have a direct or indirect impact on weeds and their competitive ability. In some cases, specific microbes have a detrimental effect on the weeds and can be exploited as biological control agents. The ubiquitous mycorrhizal fungi are beneficial symbionts that can impart a competitive advantage to their plant hosts, particularly if mycorrhizal dependency is exhibited in weeds as opposed to crops. It may be possible to exploit various soil microbes by directly or indirectly reducing weed competition and tipping the competitive advantage in favor of the crop. However, information available on microbial/ weed/crop relationships is limited and research efforts are required to explore the use of soil microorganisms as another weed management tool.

Boyetchko, S.M. 1996. Impact des microorganismes du sol sur la biologie et l'écologie des mauvaises herbes. PHYTOPROTECTION 77 : 41-56.

Quoique les populations de mauvaises herbes aient été traditionnellement réprimées par des méthodes chimiques et culturales, la lutte biologique par inondation du milieu avec des agents microbiens représente une stratégie supplémentaire de gestion des mauvaises herbes. Les agents pathogènes foliaires ont longtemps fait l'objet de recherches comme agents de lutte biologique potentiels, mais les microorganismes de la rhizosphère et leur influence sur la croissance et le développement des mauvaises herbes ont été ignorés jusqu'à tout récemment. Le sol de la rhizosphère contient une multitude de microorganismes, tels les rhizobactéries, les champignons phytopathogènes présents dans le sol et les champignons mycorhiziens à arbuscules, qui ont tous un impact direct ou indirect sur les mauvaises herbes et sur leur aptitude à la compétition. Dans certains cas, des microorganismes spécifiques ont un effet nuisible sur les mauvaises herbes et ils peuvent être

1. Agriculture and Agri-Food Canada, Saskatoon Research Centre, 107 Science Place, Saskatoon, Saskatchewan, Canada S7N $0 \times 2$ 
exploités comme agents de lutte biologique. Les champignons mycorhiziens, omniprésents, sont des symbiotes bénéfiques qui peuvent transmetttre un avantage compétitif à leurs plantes-hôtes, tout particulièrement si la dépendance mycorhizienne s'exprime chez les mauvaises herbes plutôt que chez les cultures. II peut être possible de tirer profit des divers microorganismes du sol en réduisant directement ou directement la compétition des mauvaises herbes et en faisant pencher l'avantage compétitif en faveur de la culture. Cependant les connaissances actuelles sur les relations entre les microorganismes, les mauvaises herbes et les cultures sont limitées. Des efforts de recherche sont requis afin d'explorer I'utilisation des microorganismes du sol comme autre outil de lutte contre les mauvaises herbes.

\section{INTRODUCTION}

Integrated weed management (IWM) comprises various aspects of crop production systems, including cultural, chemical, genetic, and biological weed control strategies (Swanton and Weise 1991; Wyse 1994). This systems approach to weed control can be implemented to reduce the competitive ability of weeds, reduce the weed seed bank, and weed emergence from the seed bank, and thus minimize the impact of weeds on crop yield (Kremer 1993; Swanton and Weise 1991). Farming practices, such as herbicide and fertilizer applications, crop rotations, and tillage have a tremendous influence on root development and the soil microflora and microfauna. Soil microorganisms may have a direct or indirect impact on root growth and development in weeds and crops, as well as an influence on the structure and composition of plants within a community (Allen 1991). The magnitude of this influence may have consequences on the performance of weeds within a crop, whether there is an increase or decrease in their ability to compete with the associated crop.

The reciprocal influences between plants and soil microbiota has led to an increasing interest in the discipline of rhizosphere ecology. However, the rhizosphere is a relatively unknown ecosystem and its impact on plant development has been largely ignored by the scientific community (Bolton et al. 1993; Zobel 1993). Due to the complexity of the rhizosphere and the various interdependent and interacting factors (i.e., physical, chemical and biotic properties), our understanding of root functions and how these functions affect plant growth has often been inferred by observations of the above-ground portion of plants. While soil has been a source of microbes for industrial and pharmaceutical use, it is currently being explored as a source of microorganisms for development of biological products in the agricultural sector (Metting 1985). It may be possible to exploit these microorganisms to manage weed populations. Schroth and Veinhold (1986) suggested that "those who enjoy studying orderly systems amenable to quantitative analysis are likely to consider rhizosphere investigations as a masochist's delight". Limited knowledge of microbial ecology has probably been one contributing factor for inconsistent field performance of microbial products and variability of results from site to site and year to year. An understanding of soil microbial ecology is required to enhance our ability to select and exploit soil microorganisms as weed management tools.

The objective of this paper is to provide an overview of soil microbial ecology, describe the soil microorganisms currently under investigation that influence crop/weed competition and to propose future research requirements necessary to advance this area of science. These topics will relate to microbial/vveed/ crop relationships and how this information can be applied to weed management systems.

\section{MICROBIAL ECOLOGY OF THE RHIZOSPHERE}

\section{The rhizosphere}

Hiltner first coined the term rhizosphere in 1904 to describe a layer of soil sur- 
rounding roots where microbial activity is stimulated (Baker 1987; Curl and Truelove 1986). The rhizosphere is not a welldefined region, but a zone with a microbial gradient initiating from the root surface (rhizoplane) and extending a few millimeters into the soil (Metting 1985). Portions of the rhizosphere can be called the mycorrhizosphere, where mycorrhizal fungi are associated with roots (Linderman 1988). The rhizosphere effect is a stimulation of microbial activity as a result of the secretion of organic compounds (e.g., sugars, amino acids, organic acids, vitamins, and enzymes) from the root, thus providing a source of energy for the soil microflora (Baker 1987; Bolton et al. 1993; Rovira 1969). Levels of phosphorus in plants appear to regulate root exudation through an effect on phospholipids that are associated with root membrane permeability (Graham et al. 1981; Ratnayake et al. 1978). Motility and chemotactic responses toward nutrient-rich root exudates appear to be key attributes for the success of rhizosphere microorganisms, with chemotaxis representing a competitive advantage for soil microbes to quickly become established on the root (Scher et al. 1985).

The composition of the rhizosphere can be altered through the application of soil microorganisms, such as bacteria or fungi, to seeds or roots of plants. Rhizosphere microorganisms, whether indigenous or artificially introduced, can have positive, negative, or neutral effects on plant growth or can interact with other members of the soil microbial community (Bolton et al. 1993). In natural ecosystems, the relationship between microbial populations and plants has co-evolved, but farming practices, such as cultivation, may interfere with that relationship (Linderman and Paulitz 1990). It may be possible to partially restore the association between soil microbes and plant roots by inoculation of the soil with specific microbial agents. This manipulation of the soil microflora may lead to control of soil-borne diseases and weeds, as well as growth promotion of crop plants by soil microorganisms such as mycorrhizal fungi, Rhizobium spp. and beneficial rhizobacteria (Schroth and Weinhold 1986). Moreover, managing the rhizosphere by applying microorganisms or combina- tions of various microorganisms with multiple purposes to improve crop production could provide plants with benefits that are not possible with chemicals (Paulitz and Linderman 1991).

\section{Weed management through biological control}

Biological control, which is the use of biotic agents to suppress pests, is an underutilized pest management strategy that can play a significant role in developing low-input sustainable agriculture (Baker 1987; Hoy 1990). It can provide additional means for controlling pests, such as weeds, while reducing the reliance on chemical pesticides, maintaining economic viability and environmental quality, and addressing the consumer's need for safe and nutritious food (Agriculture Canada 1993). During recent history, the primary method of weed control has been with chemical herbicides, particularly because they are relatively cheap and effective, and their application is not labor intensive (Burnside 1993; Wyse 1994). Unfortunately, the reliance on chemicals has promoted the development of monoculture cropping rather than a systems approach to weed management and, although weed eradication may not be an achieveable goal, millions of dollars have been invested to develop chemicals to control or eradicate noxious weeds (Burnside 1993). Biocontrol should be perceived as a complementary tool for weed management where it would be integrated with other weed control methods (e.g., chemical herbicides), not act as a replacement for them. However, for biological control to be successful as a weed management tool, it will be necessary to develop an environment that will sustain biological control agents. This strategy is an applied technology that enhances or mimics nature and can be utilized to maintain pest populations at non-damaging levels but not necessarily eradicate them.

The two main types of strategies for controlling weeds through biological control are the classical (inoculative), and inundative (augmentative) approaches (Charudattan 1991; TeBeest et al. 1992; Watson 1991). The classical approach involves the release of the biotic agent, i.e. natural enemy, followed by its estab- 
lishment and dissemination. The agent reduces the weed population below the socio-economic or ecological threshold and provides long-term control, with no requirement for reintroducing the agent (Hasan and Ayres 1990; TeBeest et al. 1992). The inundative approach, often referred to as the bioherbicide or mycoherbicide approach when fungi are used, involves the periodic application of a pathogen to control a weed (Charudattan 1991; TeBeest et al. 1992; Wapshere et al. 1989). In this latter case, a host-specific pathogen is mass-produced artificially and applied at high concentrations to a target weed. The biocontrol agent is not expected to provide control beyond one season after application.

Traditionally, researchers have focused on foliar fungal pathogens for biological weed control (Charudattan 1991). Hasan and Ayres (1990) suggested that the more successful weed biocontrol agents are foliar or stem applied because these fungi have a rather narrow host range and can be applied to shoots quite easily. Grass weeds, however, may be more difficult to control because their meristems are covered by leaf sheaths, thereby protecting the plant from infection by foliar fungal pathogens (Greaves and MacQueen 1992). Therefore, it may be possible to pursue soil-borne and seedborne microorganisms for control of grass weeds, but one major constraint is the lack of inoculation techniques and delivery systems for soil microbes.

Another major constraint in conducting research in biological weed control is that preliminary screening for a potential agent involves selecting and screening for it in a single plant system. Although this approach may appear to be somewhat artificial, it is also a necessary step before further research trials are conducted with crop/weed systems. Quite often the screening process is tedious, time consuming and complicated by variable seed germination. Souissi and Kremer (1994) developed a technique for screening deleterious rhizobacteria for biocontrol of weeds, based on cell cultures and callus tissues to allow rapid screening. Once field testing has been initiated, the challenge is to determine the behavior of the biocontrol agent within a particular crop with various weed species at different densities. Recently, the importance of testing weed biocontrol agents in crop/ weed mixtures was demonstrated by DiTommaso and Watson (1995) and DiTommaso et al. (1996). They found that the foliar fungal pathogen, Colletotrichum coccodes (Wallr.) Hughes had only a minor effect on velvetleaf (Abutilon theophrasti Medic.) in pure stands, but if grown in competition with soybean [Glycine max (L.) Merr.], the velvetleaf showed substantially greater growth reductions while soybean experienced concomitant increases in yield. Although many studies on the development of biological weed control agents have been based initially on single plant systerns, it was suggested that even candidates that show marginal effects on weeds in pure stands should not be rejected until they have been tested in a competitive environment (DiTommaso and Watson 1995; DiTommaso et al. 1996).

\section{Use of rhizosphere microorganisms for weed management}

Microscopically, soil is heterogeneous and can vary dramatically from microsite to microsite in physical, chemical, nutritional and microbial properties (Metting 1985). The myriad types of microorganisms existing in the soil include algae, protozoa, nitrogen-fixing bacteria, various plant-growth promoting and deleterious rhizobacteria, pathogenic and nonpathogenic fungi, and mycorrhizal fungi. In order to understand the impact of soil microorganisms on plant growth and to utilize them in crop production systems for weed control, there is a need to acquire a better understanding of the activities, population dynamics, and ecology of these organisms.

\section{Rhizobacteria}

Rhizobacteria are root-colonizing bacteria that may be classified as beneficial, deleterious, or having no effect on plants (Schippers et al. 1987; Schroth and Weinhold 1986). The assignment of the bacteria into categories may vary depending on the plant species or cultivar and the soil environment (Schroth and Weinhold 1986).

In recent years, there has been considerable interest in bacteria that enhance growth and improve yield of plants. These 
bacteria, collectively known as plant growth-promoting rhizobacteria (PGPR), metabolize seed exudates and subsequently colonize the developing root system (Kloepper and Schroth 1978). Application of PGPR in the form of seed inoculants or soil amendments has led to increases in yields of potato (Solanum tuberosum L.), sugar beet (Beta vulgaris L.), radish (Raphanus sativus L.), wheat (Triticum aestivum L.), and other crops (Kloepper and Schroth 1978; Schippers et al. 1987; Schroth and Weinhold 1986; Suslow and Schroth 1982). For example, field application of PGPR to canola (Brassica campestris $\mathrm{L}$. and $B$. napus $\mathrm{L}$.) has led to increases in yield of $11-19 \%$ (Kloepper et al. 1988). Among the bacteria possessing these growth-promoting properties are Pseudomonas fluorescens Trevisan (Migula), P. putida Trevisan (Migula), Bacillus spp., Azospirillum spp., and Azotobacter spp. Because the researchers were interested in investigating the effects of the PGPR on crops, the yield increases were noted in weed-free systems, and any activity of the bacterial isolates on weeds was ignored. In fact, the effect of the PGPR might either be beneficial, deleterious, or neutral on one or more weed species and therefore, the beneficial effect of the PGPR on the crop in a field situation could be negated if the weeds also experience plant growth promotion.

Rhizobacteria that have a negative effect on plant growth and development are called deleterious rhizobacteria (DRB) and are being pursued for biological weed control (Alström 1987; Schippers et al. 1987; Suslow and Schroth 1982). They are often overlooked because symptoms such as root discoloration, wilting, necrotic lesions and distortions of plant parts are not obvious under field conditions (Schippers et al. 1987). Furthermore, the environmental conditions favorable for the production and activity of deleterious metabolites by DRB may be absent. Kremer et al. (1990) found that the majority of DRB isolated from the rhizosphere of seven weed species were Gram-negative, most of which were Erwinia herbicola (Löhnis) Dye, Flavobacterium spp., Alcaligenes spp. and fluorescent and other pseudomonads. The number of Gram-negative rod-shaped bacteria has been found to exceed that of Gram-positive rod- and cocci bacteria in the rhizosphere soil compared to root-free soil. Also, the proportion of motile, rapidly growing bacteria (e.g., Pseudomonas spp.) is higher in rhizosphere soil than in bulk soil (Campbell 1985; Rovira and Campell 1974). Other bacterial genera identified as DRB are Enterobacter, Klebsiella, Citrobacter, Achromobacter, and Arthrobacter (Suslow and Schroth 1982). Fluorescent pseudomonads such as Pseudomonas cichorii (Swingle) Stapp, $P$. viridiflava (Burkholder) Dowson, and P. fluorescens D7 strain have also exhibited deleterious effects on growth of crops and weeds (Kennedy et al. 1991; Suslow and Schroth 1982).

Kremer et al. (1990) composed a list of desirable characteristics in DRB for consideration in the development of effective weed biocontrol agents. These include high root colonizing ability, production of specific phytotoxins, and resistance or tolerance to antibiotics produced by other rhizosphere microorganisms. More than half of the bacteria isolated from roots of several weeds produced antibiotics that inhibited growth of both the bacterium Erwinia herbicola and the fungus Fusarium oxysporum Schlecht., thereby allowing the DRB to compete with other microorganisms in the rhizosphere (Kremer et al. 1990). Rhizosphere competence, which is defined as the relative root-colonizing ability of a rhizobacterial strain, appears to be a prerequisite for bacteria to function as biocontrol agents of soil-borne plant pathogens (Milus and Rothrock 1993; Weller 1988) but whether this applies for weeds as well is not fully understood. DRB may act as exopathogens (i.e., organisms that induce plant disease without infecting plant tissue), but whether DRB invade plant roots has yet to be examined thoroughly. Begonia et al. (1990) reported a significant number of selected rhizobacteria on the rhizoplane of velvetleaf roots. The ability of the bacteria to colonize root surfaces, particularly the root hairs, was attributed to an accumulation of mucigels, which are partly derived from root cells and from microbes associated with the root. Colonization of roots by rhizobacteria may also be influenced by soil temperature 
and water, with optimum root colonization occurring under cool and moist conditions, as observed with downy brome (Bromus tectorum L.) roots colonized by P. fluorescens D7 strain (Johnson et al. 1993).

Projects exploring DRB as potential biological weed control agents in the USA and Canada are listed in Table 1. The majority of research projects have focused on crop weeds, while a group in British Columbia has initiated research on marsh reed grass [Calamagrostis canadensis (Michx.) Beauv.], a forest weed (Dorworth 1992). Many economically important weeds in agriculture belong to the Poaceae (e.g., wild oats [Avena fatua L.], green foxtail [Setaria viridis (L.) Beauv.]), yet little attempt has been made to investigate biocontrol of grass weeds with foliar pathogens. Only $11.6 \%$ of the projects targeted grass weeds (Charudattan 1991). More effort to control this group of weeds with DRB has been made (Table 1), with 6 out of 11 weeds targeted being grasses. Certainly, with the development of herbicide-resistant populations of weeds, such as wild oats and green foxtail (Beckie and Morrison 1993; Heap et al. 1993), DRB may provide a weed control option additional to chemical herbicides and cultural methods. It may also be possible to apply DRB in combination with low doses of herbicides that are compatible with DRB or would enhance DRB activity (Kremer 1993).

Boyetchko and Mortensen (1993) evaluated more than 700 rhizobacterial isolates from Western Canadian soils for their potential as biological weed control agents on downy brome and other grass weeds. In laboratory bioassays, three isolates had significant deleterious effects on downy brome with little or no negative effect occurring on winter wheat. Preliminary greenhouse trials revealed that at least one of the three isolates was capable of reducing downy brome growth in soil. Further host range tests showed that several isolates are host-specific and capable of reducing growth of green foxtail and wild oats as well. These results are consistent with those from other studies and indicate that there is potential for using rhizobacteria as biocontrol agents

Table 1. List of projects on rhizobacteria as potential biological control agents of weeds

\begin{tabular}{|c|c|c|c|c|}
\hline Weed species & Common name & Weed type ${ }^{a}$ & $\begin{array}{l}\text { Geographic } \\
\text { areab }^{b}\end{array}$ & References \\
\hline Abutilon theophrasti Medic. & Velvetleaf & $\mathrm{A}, \mathrm{H}, \mathrm{CW}$ & U.S.A. & $\begin{array}{l}\text { Begonia et al. } 1990 \\
\text { Kremer } 1987 \\
\text { Kremer et al. } 1990\end{array}$ \\
\hline Aegilops cylindrica Host. & Jointed goatgrass & $A, G, C W$ & U.S.A. & Harris and Stahlman 1992, 1993 \\
\hline Amaranthus retroflexus $\mathrm{L}$. & Redroot pigweed & $\mathrm{A}, \mathrm{H}, \mathrm{CW}$ & U.S.A. & Kremer et al. 1990 \\
\hline Avena fatua $L$. & Wild oats & $A, G, C W, R W$ & Canada & Boyetchko and Mortensen 1993 \\
\hline Bromus japonicus Thunb. & Japanese brome & $A, G, C W, R W$ & U.S.A. & $\begin{array}{l}\text { Kennedy et al. } 1991 \\
\text { Harris and Stahlman 1992, } 1993\end{array}$ \\
\hline Bromus tectorum $\mathrm{L}$. & Downy brome & $A, G, C W, R W$ & U.S.A. & $\begin{array}{l}\text { Cherrington and Elliott } 1987 \\
\text { Kennedy et al. } 1991 \\
\text { Harris and Stahlman 1992, } 1993\end{array}$ \\
\hline $\begin{array}{l}\text { Calamagrostis canadensis } \\
\text { (Michx.) Nutt. }\end{array}$ & $\begin{array}{l}\text { Marsh reed grass, } \\
\text { Blue-joint }\end{array}$ & $P, G, F W$ & $\begin{array}{l}\text { Canada } \\
\text { Canada }\end{array}$ & $\begin{array}{l}\text { Boyetchko and Mortensen } 1993 \\
\text { Dorworth } 1992\end{array}$ \\
\hline Chenopodium album L. & Lamb's-quarters & $\mathrm{A}, \mathrm{H}, \mathrm{CW}$ & U.S.A. & Kremer et al. 1990 \\
\hline Datura stramonium L. & Jimsonweed & $\mathrm{A}, \mathrm{H}, \mathrm{CW}$ & U.S.A. & Kremer et al. 1990 \\
\hline Euphorbia esula L. & Leafy spurge & $\mathrm{P}, \mathrm{H}, \mathrm{RW}$ & U.S.A. & Souissi and Kremer 1993 \\
\hline Ipomoea hederacea $\mathrm{L}$. & Ivyleaf morning glory & $A, V, C W$ & U.S.A. & Kremer et al. 1990 \\
\hline Polygonum pensylvanicum $\mathrm{L}$. & Pennsylvania smartweed & $\mathrm{A}, \mathrm{H}, \mathrm{CW}$ & U.S.A. & Kremer et al. 1990 \\
\hline Setaria viridis (L.) Beauv. & Green foxtail & $A, G, C W$ & Canada & Boyetchko and Mortensen 1993 \\
\hline Xanthium strumarium L. & Cocklebur & $\mathrm{A}, \mathrm{H}, \mathrm{CW}$ & U.S.A. & Kremer et al. 1990 \\
\hline
\end{tabular}

a A : Annual; H : Herb; CW : crop weed; G : Grass; RW : rangeland weed; P : Perennial; FW : forest weed.

b Location where research is being conducted. 
for grass weeds in cereal crops (Cherrington and Elliott 1987; Elliott and Lynch 1985; Kennedy et al. 1991).

Kennedy et al. (1991) screened more than 1000 pseudomonad bacterial isolates and found that $8 \%$ of them were inhibitory (DRB) to downy brome in laboratory bioassays, with the proportion dropping to $0.6 \%$ after evaluating them in growth chamber experiments. A bacterial isolate, P. fluorescens D7 strain, consistently reduced natural populations of downy brome, including seed production, resulting in increases in winter wheat yield of $18-35 \%$ (Kennedy et al. 1991). Although the weed was not completely eliminated from the field, these results indicated that the wheat was more competitive because of reduced weed growth and vigor caused by the rhizobacteria. Therefore, the term bioherbicide does not apply to the DRB in this case since the downy brome was not necessarily killed but its growth was reduced or delayed, resulting in an indirect benefit to the crop.

The ability of rhizobacteria to colonize both roots and residues has been demonstrated with root-colonizing Pseudomonas spp. that are deleterious to wheat (Elliott and Lynch 1984, 1985; Fredrickson and Elliott 1985a). These bacteria may produce harmful metabolites, such as phytotoxins, or may increase the susceptibility of plant roots to fungal pathogens (Åström and Gerhardson 1989; Cherrington and Elliott 1987; Elliott and Lynch 1984; Fredrickson and Elliott 1985b; Suslow and Schroth 1982). A phytotoxin from $P$. fluorescens D7 strain has been partially purified and found to cause discoloration and suppressed elongation of roots (Tranel et al. 1993a,b). Root elongation of downy brome was restored if the plant was removed from the crude preparation of the toxin, thus it was concluded that the inhibiting effect of D7 was due to a toxin. Although previous studies with the cell-free supernatant of D7 demonstrated the bacterium to be specific to downy brome (Kennedy et al. 1991), it is unclear if the phytotoxin is host-specific because studies with the crude preparation of the phytotoxin were reported for downy brome only. Gurusiddaiah et al. (1992, 1994) partially purified the toxin from D7 and found it to be a complex consisting of at least two polypeptides, fatty acid esters, and lipopolysaccharides. However, further purification or separation of any of the components from the toxin complex resulted in almost complete loss of the phytotoxicity. Because of the instability of the phytotoxic fraction, it may be more feasible to use the living organism for weed control. Gurusiddaiah et al. (1994) speculated that the toxic fraction or the bacterium itself could be encapsulated for field application. Once the mode of action and the factors that limit or enhance toxin production are understood, field management practices could be used to manipulate the activity of microbial agents and the production of phytotoxins in the rhizosphere. Genetic manipulation of microbial agents to enhance phytotoxin production may also provide an option to improve efficacy of the microbial agent.

The potential of seed-borne bacteria as weed biocontrol agents has been investigated (Kremer 1987) with distinct groups of bacteria found to be associated with particular weed species, suggesting host specificity. Of the 459 bacterial isolates evaluated, $15 \%$ were potentially phytopathogenic. Germination and seedling growth of weeds were affected by specific bacteria, with most of the DRB producing metabolites. Another study has shown that phytotoxins produced by seed-borne bacteria are able to reduce seed viability and seedling vigor (Fredrickson and Elliott 1985b). If specific microbes or microbial products associated with weed seeds could be used to kill the seeds that are dormant and persistent in the soil, it might be possible to accelerate weed seed bank depletion (Kremer 1993).

When DRB are being evaluated as potential biological weed control agents, their effects on non-target plants should also receive detailed scrutiny. Some rhizobacteria are known to be host-specific and, in some cases, a DRB in one plant may act as a PGPR in another (Boyetchko and Holmström-Ruddick 1996; Cherrington and Elliott 1987; Kennedy et al. 1991). For example, an isolate suppressive of downy brome was found to be non-detrimental to root and shoot growth of spring and winter cereal crops (Boyetchko and Holmström-Ruddick 
1996). In some cases, improvements in growth of the crop occurred, depending on the crop cultivar and rhizobacterial isolate. Cherrington and Elliott (1987) also discovered three rhizobacterial isolates that had no significant deleterious effect on winter wheat while downy brome root length was reduced by $65 \%$. Although these research findings did not indicate what the competitive outcome between the crop and weed would be, it may be possible to develop a rhizobacterial isolate as a DRB for weed control concomitantly as a PGPR, thus providing a greater competitive advantage to the crop. Another approach may be to apply a dual inoculum or a mixed inoculum of several microbial agents that are compatible with one another and use them for multiple purposes (Paulitz and Linderman 1991).

\section{Pathogenic soil-borne fungi}

Fungi in the rhizosphere may also be examined as possible biological control agents of weeds, although foliar-applied fungi have usually been the focus of investigations for use as mycoherbicides. Howell and Stipanovic (1984) reported that the fungus Gliocladium virens Miller, Giddings \& Foster was an excellent candidate as a bioherbicide because it produces viridiol, a phytotoxin showing herbicidal activity to pigweed. This fungus has generally been used as a mycoparasite (biological control agent) of the plant pathogens Sclerotinia sclerotiorum (Lib.) de Bary, Rhizoctonia solani Kühn, and Pythium ultimum Trow (Howell 1982; Tu 1980). Although viridiol is unstable when introduced into field soil, sufficient quantities of the phytotoxin to suppress weed growth were produced by the fungus when it was dried, ground and introduced into the soil (Howell and Stipanovic 1984).

Sclerotinia sclerotiorum and S. minor Jagger are fungal pathogens that have been explored as possible biocontrol agents on dandelion (Taraxacum officinale Weber) in turfgrass (Riddle et al. 1991). Reductions in amount of foliage and number of dandelion plants were found following infection with each fungus, with $S$. sclerotiorum being more effective than $S$. minor. Although both fungi infect the foliage, some isolates of $S$. minor also infect roots of some plant species and may therefore be used as soil-applied mycoherbicides. One major problem in using these fungal pathogens as mycoherbicides is that they have a wide host range, but recent biotechnological advances offer the possibility of genetically transforming isolates of Sclerotinia into non-sporulating isolates to reduce their spread to nontarget plants (Sands et al. 1990). Furthermore, it has been suggested that reducing the survival and host range of fungal pathogens through genetic manipulations may result in a new type of bioherbicide that uses broad spectrum pathogens reconstructed for directed and selective growth. Genetic manipulation of microorganisms to enhance desirable traits is an irınovative approach in bioherbicide research, but one that will require acceptance by the general public.

\section{Mycorrhizal fungi}

The most common of all soil-borne fungi are arbuscular mycorrhizal (AM) fungi. These fungi are mutualistic, symbiotic fungi that form associations with the roots of approximately $90-95 \%$ of all vascular plants (Gerdemann 1968; Hayman 1981; Mosse 1973). Some benefits that accrue to plants from this relationship are improved plant growth and yield, increased nutrient uptake (e.g., phosphorus, zinc, copper, and water), and suppression of plant diseases (Boyetchko 1991; Boyetchko and Tewari 1996; Hayman 1983; Schenck 1981). Hyphae of AM fungi act as extensions of the root systern that enable exploitation of a greater volume of soil than is accomplished by roots of nonmycorrhizal plants. Most research indicates that a major contribution of AM fungi to plants is through increased assimilation of relatively immobile soil nutrients, such as phosphorus, especially when soils are deficient in these elements (Hayman 1981, 1983). Plants with highly developed root systems may not necessarily derive as great a benefit from the mycorrhizal symbiosis as plants with less developed or sparse root systems (Hayman 1983; Koide and Li 1991).

Members of some plant families may become colonized with AM fungi to a limited extent but do not derive any benefit from them and are therefore considered to be nonmycorrhizal plants. Allen 
et al. (1989) described nonmycotrophic plants as those that reject mycorrhizal fungi, while facultative mycotrophic plants, which are perhaps the most common group, can survive with or without these fungi. Some plant families that are nonmycotrophic include Brassicaceae, Chenopodiaceae, and Polygonaceae (Glenn et al. 1985; Hayman 1981). Many important weeds are members of these families. Mycorrhizal dependency in a plant species has been defined as "the degree to which a plant is dependent on the mycorrhizal condition to produce its maximum growth or yield, at a given level of soil fertility" (Gerdemann 1975). The extent of dependency of plants on mycorrhizal symbiosis varies, but for plants in undisturbed, native ecosystems, the relationship is considered essential (Linderman and Paulitz 1990). In agroecosystems, production inputs of fertilizers, pesticides, etc. may have a detrimental effect on AM fungi and their ability to colonize plant roots. If use of fertilizers, pesticides, etc. are to be reduced, increasing mycorrhizal susceptibility and, hence, dependency in crops may be essential for making agriculture sustainable.

Arbuscular mycorrhizal fungi colonize roots of cereal crops and, in some cases, will improve crop yield (Boyetchko 1991; Hetrick et al. 1992, 1993). Because wheat is a major cereal crop worldwide, there has been considerable interest in improving yield under low-input agriculture through management of the mycorrhizal symbiosis. Hetrick et al. (1992) studied the dependency of modern wheat varieties, landraces, and ancestors on mycorrhizal fungi and found that modern wheat cultivars derived less benefit from the symbiosis than primitive varieties and Asian landraces. Boyetchko $(1986,1991)$ also observed low root colonization levels by mycorrhizal fungi in 22 Canadian barley cultivars while roots of wild barley (Hordeum vulgare L.), a perennial weed, were colonized by mycorrhizal fungi to a greater extent (as much as $55 \%$ of their roots). It is possible that the mycorrhizal symbiosis trait may have been lost in the process of selecting for resistance to plant diseases.

Based on the research by Hetrick et al. $(1992,1993)$, wild, uncultivated plants not only become colonized by AM fungi to a greater extent than cultivated crops, but they may have a greater dependency on the mycorrhizal symbiosis. Competition has been defined as "a depletion of resources by an individual plant to the detriment of a neighbour" (Miller and Allen 1992) and it has been postulated that mycorrhizal fungi improve the competitive ability of a host plant to the detriment of a neighbouring nonmycotrophic plant. Allen and Allen (1986) observed that the addition of mycorrhizal fungi to field soil led to an increase in the ability of mycotrophic grasses to extract water from the soil when in competition with annual weed species. However, they could not detect any differences in the nutrient levels of the plants attributable to mycorrhizal associations.

There has been a limited amount of research on the importance of mycorrhizal associations on weeds and how the symbionts affect their competitive ability. Some researchers have reported the presence of AM fungi in roots of weeds such as velvetleaf, yellow foxtail [Setaria glauca (L.) Beauv.], lamb's-quarters (Chenopodium album L.), annual sow-thistle (Sonchus oleraceus L.), Russian thistle (Salsola pestifer A. Nels.), and wild oats (Hirrell et al. 1978; Koide 1991; Koide and Lu 1992; Koide et al. 1988; Schmidt and Reeves 1984). Schmidt and Reeves (1984) revealed that, although roots of Russian thistle (Chenopodiaceae, nonmycotrophic) were not colonized with mycorrhizal fungi to a great extent, they may play an important role in stabilizing the population of AM fungi in soil.

Koide and Lu (1992) studied the influence of mycorrhizal fungi on vigor and fitness of wild oats offspring. When roots of wild oats mother plants were infected with AM fungi, the offspring had a higher nutrient content of the shoots and roots and greater leaf areas than offspring from nonmycorrhizal mother plants. Although seed weight of the offspring wild oats plants were reduced significantly, the number of seeds per spikelet and the phosphorus concentration of the seed increased. It was thus concluded that mycorrhizal fungi conferred a positive effect on the offspring of wild oats mother plants and that these mycorrhizal symbi- 
oses have a significant influence on plant fitness and offspring vigor. Therefore, there is a significant effect of mycorrhizal fungi on the competitive ability of wild oats. However, Koide et al. (1988) found that, although both wild and cultivated oats infected with mycorrhizal fungi experienced increases in vegetative growth when compared to nonmycorrhizal plants, the benefits conferred were much greater in cultivated than wild oats, generating the possibililty that mycorrhizal cultivated oats could out-compete mycorrhizal wild oats in a cropping situation. Only one cultivar of cultivated oats was tested by Koide et al. (1988) and it is not known whether this particular cultivar was highly responsive to mycorrhizal symbiosis or if there are other cultivars of oats that may be less responsive or less dependent on mycorrhizal fungi. The same may be said for the wild oats population studied and other wild oats populations.

With the growing trend towards lowinput agriculture, breeding programs should consider mycorrhizal associations as a desirable characteristic in crops such as wheat, barley and oats. Wyse (1994) suggested that one priority in weed science be the development of crop varieties with enhanced crop interference potential. Therefore, through diligent screening and selection of crop cultivars for susceptibility to mycorrhizal colonization and where the crop derives a benefit from the symbiosis (i.e., selecting for mycotrophy and mycorrhizal dependency in crop cultivars), it may be possible to increase the competitive ability of the crops in the presence of the various weeds that may be growing in the field. Mycorrhizal dependency may impart a greater competitive advantage to weed species in an agricultural cropping system and it is possible that plant communities can be altered by mycorrhizal fungi, depending on the mycorrhizal status of the crop and the weed. If crop plants are either nonmycotrophic or have a low mycorrhizal dependency, mycotrophic weeds may have a competitive advantage. The competitive balance may tip in favor of plants that access a greater amount of resources as a result of their mycorrhizal association. Furthermore, it may be desirable to manipulate the mycorrhizal symbiosis through management of the rhizosphere so it is more favorable to the crop than the weed and to recommend to farmers those crop cultivars that exhibit a higher susceptibility and dependency on mycorrhizal fungi.

\section{APPLICATION OF MICROBIAL INOCULANTS}

To date, little effort has been made to develop effective application methods for soil microbes used in biological weed control. Most research that has focused on soil microbial inoculants to improve plant growth (i.e., biofertilizers or biocontrol agents of plant diseases) has relied on the placement of the microorganisms on or within the vicinity of the crop seed (Kremer 1986). Innovative strategies will have to be developed to target the weed seeds or roots that can occur in the soil at different depths throughout the soil profile, depending on the weed species, and where seed germination is variable (in part due to seed dormancy). The aim will be to attract particular rhizobacteria to weed seedlings either by seed or root exudates, or to use specific rhizobacterial isolates that produce toxic metabolites that selectively inhibit growth of the weeds but not the crops. How this is accomplished will be the challenge.

While it should be borne in mind that agriculture has a rich history of inventiveness and an established record of rapid adoption of new technologies, microbial agents for biological weed control are not commercially available on an extensive basis. Until a regular market for microbial agents for biological control has been established and the use of these agents is integrated into weed management practices, farmers may not be willing to invest in new equipment for their application. Therefore, microbial inoculants in agriculture should initially be sold in a form that can be easily used by farmers, compatible with existing farm equipment and practices and not require new equipment or application techniques which would preclude farmers from using the product (Glass 1993). Nonetheless, this should not restrict the development of new technology, such as new delivery systems, that could determine the overall success of biological weed 
control. Lack of reliable field performance, often observed with soil microbes used in biological control, has probably been the result of instability of the biocontrol agents, loss of cell viability, desiccation of inoculum, or sensitivity to adverse environmental factors (Glass 1993; Greaves 1993; Thomashow and Weller 1990). These problems may be overcome through novel technological advances in formulation and application technology.

Several types of carriers have been used to apply soil microbes. For example, peat has been a traditional carrier of Rhizobium inoculants while peat-based seed pellets have been used with rhizobacteria and AM fungi to provide bulk to coated seeds and allow more inoculum per seed (Jarstfer and Sylvia 1993; Thomashow and Weller 1990). Sometimes, an adhesive is added to the fine peat to facilitate sticking. To improve root colonization by AM fungi, expanded clay pellets have been applied through the same tube as maize seeds from an air-powered seed drill (Hayman et al. 1981). Coating seeds with rhizobacteria is often referred to as seed bacterization. Materials that have been used to apply the bacteria, in addition to the peat, are diatomaceous earth, adhesive clays such as talc and vermiculite, cellulose derivatives (e.g., carboxy-methyl-cellulose), and other polymers such as xanthan (Digat 1989). If microbes are coated onto seeds, they must be tolerant to toxins found in seed coats and compatible with seedapplied chemicals, which may be bactericidal or affect root colonization. Once the bacterial agents have been applied to the seed, release of bacterial cells into the soil and to the root after germination must occur. Several polymers, such as polyacrylamide and sodium alginate, are now available for encapsulation of seeds with gel entrapped bacteria (Digat 1989; Glass 1993; Jha et al. 1993). These gelling agents immobilize the microbes and trap water, thus reducing desiccation of cells. Alginate pellets have also been used as a delivery system for AM fungi (Jarstfer and Sylvia 1993). Soil microbes may be delivered to the soil in granular form and banded at planting or applied as a liquid, similar to fertilizers, but the technique for delivery of microbial inocula will be dependent on the crop, the weeds, and the farming practices (Glass 1993; Schroth and Weinhold 1986).

Root-colonizing Pseudomonas spp. have the ability to grow not only on roots but on residues, with crops seeded into no-till plots supporting higher populations of rhizobacteria than crops seeded into tilled plots (Elliott and Lynch 1984, 1985; Fredrickson and Elliott 1985a; Stroo et al. 1988). Stroo et al. (1988) introduced a Pseudomonas species that survived the winter on barley residues in the field and populations of $10^{6} \mathrm{cfu} \mathrm{g}^{-1}$ straw were recovered. The bacteria introduced on the barley residue were able to colonize the roots of the winter wheat crop, thereby demonstrating that bacteria from a preceding crop can colonize the roots of a subsequent crop. With the growing trend towards conservation tillage, crop residues may prove to be an easy and inexpensive vehicle for delivery of microbial inoculants to the rhizosphere but, to date, very little has been done to exploit this possibility for weed management purposes.

Cropping systems may exert an effect on soil microbial activity. Long-term fallowing of fields has been shown to be detrimental to AM fungal populations, with sporulation of various mycorrhizal species being influenced by cropping sequences (Thompson 1987). Inclusion of mycorrhizal plants (e.g., legumes) in a cropping system can be used to increase populations of AM fungal spores in soil while nonmycorrhizal plants (e.g., Brassica spp. such as rapeseed) may reduce AM fungal populations (Baltruschat and Dehne 1988). Douds et al. (1993) investigated the effect of different farming systems (i.e., conventional vs low-input) on mycorrhizal populations and colonization of roots of maize and soybean and revealed that low-input plots had higher densities of mycorrhizal fungal spores than conventionally farmed plots. Various farming practices could be used to manage soil microorganisms such as mycorrhizal fungi and rhizobacteria (such as DRB for weed control) to optimize crop yields and reduce weed competition. 


\section{RECOMMENDATIONS}

The rhizosphere contains a variety of microorganisms that have a direct or indirect impact on plants, but it has often been neglected when the impact of biotic and abiotic factors on plant growth and development have been studied. By manipulating the microorganisms in the rhizosphere through various crop management strategies, it may be possible to utilize soil microbes as part of an IWM strategy.

The use of soil microorganisms for weed management has potential but research efforts are required in the following areas before this becomes possible :

1) Study the ecology of the rhizosphere and microbial community. Multidisciplinary research is needed to understand the complex interactions of biotic, physical, and chemical processes that occur in the rhizosphere ecosystem and what impact these factors have on rhizosphere microorganisms. Many of our observations on plant growth have been inferred from the above-ground portions of plants; some plant growth responses may be the direct or indirect result of the activities of rhizosphere microbes.

2) Develop biological weed control strategies with rhizosphere microorganisms. There is a need to investigate soil microorganisms as potential weed control agents. Current research in weed biocontrol has focused mainly on bioherbicides to eradicate weeds. It is believed that soil microorganisms can be used to reduce competition from target weeds in a crop, thereby reducing weed growth and reproductive ability, and hence, the number of weed seeds in the soil. Scientists in weed ecology and biocontrol need to consider what is an acceptable level of weed control from an agricultural perspective and whether eradication of weeds should be the goal. With current trends to develop more sustainable and integrated weed management strategies, weed control through biological means offers an additional approach that can complement existing cultural and chemical control methods while reducing herbicide rates.

3) Understand how rhizosphere microorganisms influence crop/weed interference. The majority of research investigating the effects of microorganisms on plant growth has focused on single plant systems. If soil microbes are to be pursued for biological control, their potential should be evaluated in mixed stands containing both the crop and weed, where the competitive outcome can be determined. In addition, crop breeding programs should involve developing varieties with improved competitiveness. While weed ecologists have been studying competition between weeds and crops, it may be possible to select crops that are more competitive because of mycorrhizal dependency.

4) Develop effective delivery systems (application technology) for utilizing rhizosphere microorganisms for weed management. The interaction of various microbial products when used in combination and the possible development of inoculum packages vhere several microbes can be utilized for multiple purposes should be explored.

\section{ACKNOWLEDGEMENTS}

I wish to thank Dr. A.G. Thomas (Agriculture and Agri-Food Canada, Saskatoon) for his thoughtful review of the manuscript.

\section{REFERENCES}

Agriculture Canada. 1993. Research branch business plan 1993-1994. Agriculture Canada Publication 1897/E, Ottawa, 32 pp.

Allen, M.F. 1991. The ecology of mycorrhizae. Cambridge Univ. Press, Cambridge, New York. 184 pp.

Allen, E.B., and M.F. Allen. 1986. Water relations of xeric grasses in the field : Interactions of mycorrhizae and competition. New Phytol. 104 : 559-571.

Allen, M.F., E.B. Allen, and C.F. Friese. 1989. Responses of the non-mycotrophic plant Salsola kali to invasion by vesicular-arbuscular mycorrhizal fungi. New Phytol. 111: 45-49. 
Alström, S. 1987. Factors associated with detrimental effects of rhizobacteria on plant growth. Plant Soil 102 : 3-9.

Åström, B., and B. Gerhardson. 1989. Wheat cultivar reactions to deleterious rhizosphere bacteria under gnotobiotic conditions. Plant Soil 117: 157-165.

Baker, K.F. 1987. Evolving concepts of biological control of plant pathogens. Annu. Rev. Phytopathol. 25 : 67-85.

Baltruschat, H., and H.W. Dehne. 1988. The occurrence of vesicular-arbuscular mycorrhiza in agro-ecosystems. I. Influence of nitrogen fertilization and green manure in continuous monoculture and in crop rotation on the inoculum potential of winter wheat. Plant Soil $107: 279-284$.

Beckie, H.J., and I.N. Morrison. 1993. Effect of ethalfluralin and other herbicides on trifluralin-resistant green foxtail (Setaria viridis). Weed Technol. $7: 6-14$.

Begonia, M.F.T., R.J. Kremer, L. Stanley, and A. Jamshedi. 1990. Association of bacteria with velvetleaf roots. Trans. Mo. Acad. Sci. 24 : 17-26.

Bolton, H., Jr., J.K. Fredrickson, and L.F. Elliott. 1993. Microbial ecology of the rhizosphere. Pages 27-63 in: F. Blaine Metting Jr. (ed.), Soil microbial ecology. Applications in agricultural and environmental management. Marcel Dekker, Inc., New York.

Boyetchko, S.M. 1986. Glomus dimorphicum Boyetchko \& Tewari sp. nov. mycorrhizal with barley in Alberta : taxonomy, host colonization, and hyperparasitism. M.Sc. thesis, University of Alberta, Edmonton, Alberta, $172 \mathrm{pp}$.

Boyetchko, S.M. 1991. Biological control of the common root rot of barley through the use of vesicular-arbuscular mycorrhizal fungi. Ph.D. thesis, University of Alberta, Edmonton, Alberta, 192 pp.

Boyetchko, S.M., and B. Holmström-Ruddick. 1996. Host-range of rhizobacteria effective as biocontrol agents of downy brome. Can. J. Plant Pathol. 18 : 86-87 (Abstract).

Boyetchko, S.M., and K. Mortensen. 1993. Use of rhizobacteria as biological control agents of downy brome. Pages 443-448 in: Proc. Soils \& Crops Workshop '93, Saskatoon, Sask., February 25-26, 1993.

Boyetchko, S.M., and J.P. Tewari. 1996. Use of VA mycorrhizal fungi in soil-borne disease management. Pages 146-163 in : R.S. Utkhede and V.K. Gupta (eds.), Management of soil-borne diseases, Kalyani Publishers, Ludhiana $(\mathrm{Pb})$, India.
Burnside, O.C. 1993. Weed science - the step child. Weed Technol. 7 : 515-518.

Campbell, R. 1985. Plant microbiology. Edward Arnold Publishers, London. 191 pp.

Charudattan, R. 1991. The mycoherbicide approach with plant pathogens. Pages 2457 in : D.O. TeBeest (ed.), Microbial control of weeds, Chapman \& Hall Inc., New York.

Cherrington, C.A., and L.F. Elliott. 1987. Incidence of inhibitory pseudomonads in the Pacific Northwest. Plant Soil. 101: 159165.

Curl, E.A., and B. Truelove. 1986. The rhizosphere, Springer-Verlag, New York. 280 pp.

Digat, B. 1989. Strategies for seed bacterization. Acta Hortic. 253 : 121-130.

DiTommaso, A., and A.K. Watson. 1995. Impact of a fungal pathogen, Colletotrichum coccodes on growth and competitive ability of Abutilon theophrasti. New Phytol. $131: 51-60$.

DiTommaso, A., A.K. Watson, and S.G. Hallett. 1996. Effect of the fungal pathogen, Colletotrichum coccodes, on velvetleaf (Abutilon theophrasti) - soybean competition in the field. in Proceedings of the IX International Symposium on Biological Control of Weeds, South Africa, January 21-26, 1996 (in press).

Dorworth, C. 1992. The case for biological control - Deleterious rhizobacteria as biocontrol agents for Calamagrostis canadensis. Northern Forest Vegetation Manager. pp. 9-11.

Douds, D.D., Jr., R.R. Janke, and S.E. Peters. 1993. VAM fungus spore populations and colonization of roots of maize and soybean under conventional and low-input sustainable agriculture. Agric. Ecosyst. Environ. 43 : 325-335.

Elliott, L.F., and J.M. Lynch. 1984. Pseudomonads as a factor in the growth of winter wheat (Triticum aestivum L.). Soil Biol. Biochem. $16: 69-71$.

Elliott, L.F., and J.M. Lynch. 1985. Plant growth-inhibiting pseudomonads colonizing winter wheat (Triticum aestivum L.) roots. Plant Soil 84 : 57-65.

Fredrickson, J.K., and L.F. Elliott. 1985a. Colonization of winter wheat roots by inhibitory rhizobacteria. Soil Sci. Soc. Am. J. $49: 1172-1177$.

Fredrickson, J.K., and L.F. Elliott. 1985b. Effect on winter wheat seedling growth by toxin-producing rhizobacteria. Plant Soil 83 : 399-409. 
Gerdemann, J.W. 1968. Vesicular-arbuscular mycorrhizae and plant growth. Annu. Rev. Phytopathol. $6: 397-418$.

Gerdemann, J.W. 1975. Vesicular-arbuscular mycorrhiza. Pages 575-591 in: J.G. Torry and D.T. Clarkson (eds.), The development and function of roots, Academic Press, New York.

Glass, D.J. 1993. Commercialization of soil microbial technologies. Pages 595-618 in: F. Blaine Metting Jr. (ed.), Soil microbial ecology. Applications in agricultural and environmental management, Marcel Dekker Inc., New York.

Glenn, M.G., F.S. Chew, and P.H. Williams. 1985. Hyphal penetration of Brassica (Cruciferae) roots by a vesicular-arbuscular mycorrhizal fungus. New Phytol. 99 : 463472.

Graham, J.H., R.T. Leonard, and J.A. Menge. 1981. Membrane-mediated decrease in root exudation responsible for phosphorus inhibition of vesicular-arbuscular mycorrhiza formation. Plant Physiol. 68 : 548552.

Greaves, M.P. 1993. Formulation of microbial herbicides to improve performance in the field. Pages 219-225 in: Proc. $8^{\text {th }}$ EWRS Symposium "Quantitative approaches in weed and herbicide research and their practical application", Braunschweig, Germany.

Greaves, M.P., and M.D. MacQueen. 1992. Bioherbicides: their role in tomorrow's agriculture. Pages 295-306 in: Resistance: Achievements and developments in combating pesticide resistance, Sci. symposium, Harpenden, England.

Gurusiddaiah, S., D.R. Gealy, A.C. Kennedy, and A.G. Ogg, Jr. 1992. Production, isolation, and characterization of phytotoxic and fungistatic compounds for biocontrol of downy brome (Bromus tectorum L.) and plant pathogenic fungi. Weed Sci. Soc. Am. $32: 84$ (Abstract).

Gurusiddaiah, S., D.R. Gealy, A.C. Kennedy, and A.G. Ogg, Jr. 1994. Isolation and characterization of metabolites from Pseudomonas fluorescens-D7 for control of downy brome (Bromus tectorum L.). Weed Sci. 42 : 492-501.

Harris, P.A., and P.W. Stahlman. 1992. Biological weed control using deleterious rhizobacteria. Weed Sci. Soc. Am. $32: 50$ (Abstract).
Harris, P.A., and P.W. Stahlman. 1993. Soil bacteria selectively inhibit annual grass weeds in winter wheat. Page 250 in: 1993 Agronomy Abstracts (Soil Sci. Soc. Am.), Cincinnati, Ohio, November 7-12, 1993.

Hasan, S., and P.G. Ayres. 1990. The control of weeds through fungi: principles and prospects. New Phytol. 115 : 201-222.

Hayman, D.S. 1981. Mycorrhiza and its significance in horticulture. The Plantsman 2 : 214-224.

Hayman, D.S. 1983. The physiology of vesicular-arbuscular endomycorrhizal symbiosis. Can. J. Bot. 61 : 944-963.

Hayman, D.S., E.J. Morris, and R.J. Page. 1981. Methods for inoculating field crops with mycorrhizal fungi. Ann. Appl. Biol. 99: 247-253.

Heap, I.M., B.G. Murray, H.A. Loeppky, and I.N. Morrison. 1993. Resistance to aryloxyphenoxypropionate and cyclohexanedione herbicides in wild oat (Avena fatua). Weed Sci. $41:$ 232-238.

Hetrick, B.A.D., G.W.T. Wilson, and T.S. Cox. 1992. Mycorrhizal dependence of modern wheat varieties, landraces, and ancestors. Can. J. Bot. $70:$ 2032-2040.

Hetrick, B.A.D., G.W.T. Wilson, and T.S. Cox. 1993. Mycorrhizal dependence of modern wheat cultivars and ancestors : a synthesis. Can. J. Bot. $71: 512-518$.

Hirrell, M.C., H. Mehravaran, and J.W. Gerdemann. 1978. Vesicular-arbuscular mycorrhizae in the Chenopodiaceae and Cruciferae: do they occur? Can. J. Bot. 56 : 2813-2817.

Howell, C.R. 1982. Effect of Gliocladium virens on Pythium ultimum, Rhizoctonia solani, and damping-off of cotton seedlings. Phytopathology 72 : 496-498.

Howell, C.R., and R.D. Stipanovic. 1984. Phytotoxicity to crop plants and herbicidal effects on weeds of viridiol produced by Gliocladium virens. Phytopathology 74 : 1346-1349.

Hoy, M.A. 1990. Commentary: The importance of biological control in U.S. Agriculture. J. Sustain. Agric. $1:$ 59-79.

Jarstfer, A.G., and D.M. Sylvia. 1993. Inoculum production and inoculation strategiesfor vesicular-arbuscular mycorrhizal fungi. Pages 349-377 in : F. Blairie Metting, Jr. (ed.), Soil microbial ecology. Applications in agricultural and environmental management, Marcel Dekker Inc., New York. 
Jha, P.K., S. Nair, and S. Babu. 1993. Encapsulation of seeds of Sesbania sesban with polyacrylamide and alginate gel entrapped rhizobia leads to effective symbiotic nitrogen fixation. Ind. J. Exp. Biol. 31 : 161-167.

Johnson, B.N., A.C. Kennedy, and A.G. Ogg, Jr. 1993. Suppression of downy brome growth by a rhizobacterium, in controlled environments. Soil Sci. Soc. Am. J. 57 : 73-77.

Kennedy, A.C., L.F. Elliott, F.L. Young, and C.L. Douglas. 1991. Rhizobacteria suppressive to the weed downy brome. Soil Sci. Soc. Am. J. 55 : 722-727.

Kloepper, J.W., and M.N. Schroth. 1978. Plant growth promoting rhizobacteria on radishes. Pages 879-882 in: Proc. $4^{\text {th }}$ Int. Conf. Plant Pathogen. Bact., Angers : Stn. Pathol. Vegetale Phytobacteriol.

Kloepper, J.W., D.J. Hume, F.M. Scher, C. Singleton, B. Tipping, M. Laliberté, K. Frauley, T. Kutchaw, C. Simonson, R. Lifshitz, I. Zaleska, and L. Lee. 1988. Plant growth-promoting rhizobacteria on canola (rapeseed). Plant Dis. 72 : 42-46.

Koide, R.T. 1991. Density-dependent response to mycorrhizal infection in Abutilon theophrasti Medic. Oecologia 85 : 389-395.

Koide, R.T., and M. Li. 1991. Mycorrhizal fungi and the nutrient ecology of three oldfield annual plant species. Oecologia 85 : 403412.

Koide, R.T., and X. Lu. 1992. Mycorrhizal infection of wild oats : maternal effects on offspring growth and reproduction. Oecologia $90: 218-226$.

Koide, R.T., M. Li, J. Lewis, and C. Irby. 1988. Role of mycorrhizal infection in the growth and reproduction of wild vs. cultivated plants. I. Wild vs. cultivated oats. Oecologia $77: 537-543$.

Kremer, R.J. 1986. Bacteria can battle weed growth. Am. Nurseryman 164 : 162-163.

Kremer, R.J. 1987. Identity and properties of bacteria inhabiting seeds of selected broadleaf weed species. Microb. Ecol. 14 : 29-37.

Kremer, R.J. 1993. Management of weed seed banks with microorganisms. Ecol. Appl. $3: 42-52$

Kremer, R.J., M.F.T. Begonia, L. Stanley, and E.T. Lanham. 1990. Characterization of rhizobacteria associated with weed seedlings. Appl. Environ. Microbiol. 56: 1649-1655.
Linderman, R.G. 1988. Mycorrhizal interactions with the rhizosphere microflora: The mycorrhizosphere effect. Phytopathology 78 : 366-371.

Linderman, R.G., and T.C. Paulitz. 1990. Mycorrhizal-rhizobacterial interactions. Pages 261-283 in: D. Hornby (ed.), Biological control of soil-borne plant pathogens, CAB International, Redwood Press Ltd., Melksham, Wiltshire, Great Britain.

Metting, B. 1985. Soil microbiology and biotechnology. Pages 196-214 in : P.N. Cheremisinoff and R.P Ouellette (eds.), Biotechnology applications and research. Technomic Publ. Co., Inc., Pennsylvania.

Miller, S.L., and E.B. Allen. 1992. Mycorrhizae, nutrient translocation, and interactions between plants. Pages 301-332 in : M.F. Allen (ed.), Mycorrhizal functioning, Chapman \& Hall, New York.

Milus, E.A., and C.S. Rothrock. 1993. Rhizosphere colonization of wheat by selected soil bacteria over diverse environments. Can. J. Microbiol. 39 : 335-341.

Mosse, B. 1973. Advances in the study of vesicular-arbuscular mycorrhizas. Annu. Rev. Phytopathol. 11 : 171-196.

Paulitz, T.C., and R.G. Linderman. 1991. Mycorrhizal interactions with soil organisms. Pages 77-129 in : D.K. Arora, B. Rai, K.G. Mukerji, and G.R. Knudsen (eds.), Handbook of applied mycology. Volume 1 : Soil and plants, Marcel Dekker Inc., New York.

Ratnayake, M., R.T. Leonard, and J.A. Menge. 1978. Root exudation in relation to supply of phosphorus and its possible relevance to mycorrhizal formation. New Phytol. 81 : 543-552.

Riddle, G.E., L.L. Burpee, and G.J. Boland. 1991. Virulence of Sclerotinia sclerotiorum and S. minor on dandelion. Weed Sci. 39 : 109-118.

Rovira, A.D. 1969. Plant root exudates. Bot. Rev. 35 : 35-57.

Rovira, A.D., and R. Campbell. 1974. Scanning electron microscopy of microorganisms on roots of wheat. Microbial Ecol. 1 : 15-23.

Sands, D.C., E.J. Ford, and R.V. Miller. 1990. Genetic manipulation of broad host-range fungi for biological control of weeds. Weed Technol. 4 : 471-474.

Schenck, N.C. 1981. Can mycorrhizae control root disease? Plant Disease 65 : 231-234. 
Scher, F.M., J.W. Kloepper, and C.A. Singleton. 1985. Chemotaxis of fluorescent $P$ seudomonas spp. to soybean seed exudates in vitro and in soil. Can. J. Microbiol. 31 : 570-574.

Schippers, B., A.W. Bakker, and P.A.H.M. Bakker. 1987. Interactions of deleterious and beneficial rhizosphere microorganisms and the effect of cropping practices. Annu. Rev. Phytopathol. 25 : 339-358.

Schmidt, S.K., and F.B. Reeves. 1984. Effect of the non-mycorrhizal pioneer plant Salsola kali L. (Chenopodiaceae) on vesiculararbuscular mycorrhizal (VAM) fungi. Am. J. Bot. 71 : 1035-1039.

Schroth, M.N., and A.R. Weinhold. 1986. Rootcolonizing bacteria and plant health. HortScience 21: 1295-1298.

Souissi, T., and R.J. Kremer. 1993. Impact of rhizobacteria on leafy spurge (Euphorbia esula L.) growth. Page 260 in: 1993 Agronomy Abstracts (Soil Sci. Soc. Am.), Cincinnati, Ohio, November 7-12, 1993 (Abstract).

Souissi, T., and R.J. Kremer. 1994. Leafy spurge (Euphorbia esula) cell cultures for screening deleterious rhizobacteria. Weed Sci. 42 : 310-315.

Stroo, H.F., L.F. Elliott, and R.I. Papendick. 1988. Growth, survival and toxin production of root-inhibitory pseudomonads on crop residues. Soil Biol. Biochem. 20: 201-207.

Suslow, T.V., and M.N. Schroth. 1982. Role of deleterious rhizobacteria as minor pathogens in reducing crop growth. Phytopathology $72: 111-115$.

Swanton, C.J., and S.F. Weise. 1991. Integrated weed management: the rationale and approach. Weed Technol. 5 : 657-663.

TeBeest, D.O., X.B. Yang, and C.R. Cisar. 1992. The status of biological control of weeds with fungal pathogens. Annu. Rev. Phytopathol. 30 : 637-657.
Thomashow, L.S., and D.M. Weller. 1990. Application of fluorescent pseudomonads to control root diseases of wheat and some mechanisms of disease suppression. Pages 109-122 in: D. Hornby (ed.), Biological control of soil-borne plant pathogens, $C A B$ International, Redwood Press Ltd., Melksham, Wiltshire, Great Britain.

Thompson, J.P. 1987. Decline of vesiculararbuscular mycorrhizae in long fallow disorder of field crops and its expression in phosphorus deficiency of sunflower. Austr. J. Agric. Res. $38: 847-867$.

Tranel, P.J., D.R. Gealy, and G.P. Irzyk. 1993a. Physiological responses of downy brome (Bromus tectorum) roots to Pseudomonas fluorescens strain D7 phytotoxin. Weed Sci. $41: 483-489$

Tranel, P.J., D.R. Gealy, and A.C. Kennedy. 1993b. Inhibition of downy brome (Bromus tectorum L.) root growth by a phytotoxin from Pseudomonas fluorescens strain D7 phytotoxin. Weed Sci. 41 : 483-489.

Tu, J.C. 1980. Gliocladium virens, a destructive mycoparasite of Sclerotinia sclerotiorum. Phytopathology 70 : 670-674.

Wapshere, A.J., E.S. Delfosse, and J.M. Cullen 1989. Recent developments in biological control of weeds. Crop Prot. 8 : 227-250.

Watson, A.K. 1991. The classical approach with plant pathogens. Pages 3-23 in: D.O. TeBeest (ed.), Microbial control of weeds, Chapman \& Hall Inc., New York.

Weller, D.M. 1988. Biological control of soilborne plant pathogens in the rhizosphere with bacteria. Annu. Rev. Phytopathol. 26 : 379-407.

Wyse, D.L. 1994. New technologies and approaches for weed management in sustainable agriculture systems. Weed Technol. 8 : 403-407.

Zobel, R.W. 1993. The rhizosphere - A great unknown. Agric. Res. 41: 2. 